\title{
MODEL EKONOMI RUMAHTANGGA PERTANIAN USAHA PADI PENERIMA PKH KABUPATEN KARAWANG
}

\author{
Arham Rivai*, Bonar M. Sinaga**, Hermanto Siregar**, Harianto** \\ *Badan Pusat Statistik, Jakarta-Indonesia \\ **Fakultas Ekonomi dan Manajemen IPB, Bogor-Indonesia \\ E-mail:*arham@bps.go.id
}

\begin{abstract}
Abstrak
Kebijakan pertanian dan program perlindungan sosial diperlukan untuk meningkatkan kesejahteraan dan menurunkan kemiskinan rumahtangga pertanian, tetapi sedikit perhatian diberikan kepada interaksi kedua kebijakan. Penelitian bertujuan untuk membangun model ekonomi rumahtangga petani usaha padi penerima PKH dan menganalisis dampak kebijakan pertanian, program perlindungan sosial, dan integrasi kedua kebijakan terhadap kinerja ekonomi dan kesejahteraan rumahtangga pertanian, serta pengaruhnya terhadap jumlah penduduk miskin di Kabupaten Karawang. Penelitian menggunakan data cross section pada 158 rumahtangga petani padi penerima PKH. Model dibangun sebagai sistem persamaan simultan yang terdiri dari 18 persamaan struktural dan 22 persamaan identitas. Estimasi model menggunakan metode two-stage least squares (2SLS). Hasil menunjukkan bahwa model yang dibangun dapat diaplikasikan kemampuannya untuk melakukan simulasi kebijakan dan dapat digunakan untuk mengevaluasi alternatif dampak kebijakan yang relevan terhadap kesejahteraan rumahtangga petani. Sedangkan hasil analisis menunjukkan bahwa PKH dapat berguna untuk mengkompensai kesejahteraan yang hilang sebagai akibat kebijakan pertanian berupa pengurangan subsidi pupuk serta merupakan instrumen yang dapat disinergikan dengan kebijakan pertanian.
\end{abstract}

Kata kunci: kebijakan pertanian, program perlindungan sosial, rumahtangga pertanian, subsidi pupuk

\begin{abstract}
Both agricultural policy and social protection programmes are needed to improving welfare and reduce poverty among agricultural households, but little attention has been paid to the interaction between them. The study aims to build agricultural household economic model of PKH recipient rice farming and analyze the impact of agricultural policies, social protection programs, and the integration of both policies on the economic performance and welfare of agricultural households, and their effects on the number of poor people in Karawang District. The study used cross section data on 158 PKH recipient rice farming households. The model was built as a system of simultaneous equations consisting of 18 structural equations and 22 identity equations were estimade using the two-stage least squares (2SLS) method. The results show that the model can be applied to carry out policy simulations and can be used to evaluate alternative impacts of relevant policies on the welfare of farm households. While the results of the analysis show that PKH can be useful to compensate for the lost welfare as a result of reduction in fertilizer as well as an instrument that can be synergized with agricultural policy.
\end{abstract}

Keywords: agricultural policy, agricultural household, fertilizer subsidy, social protection programmes 


\section{PENDAHULUAN}

Menurut Singh et al. (1986), salah satu persoalan besar bagi negara-negara berkembang adalah bahwa upaya untuk memprediksi dampak dari kebijakan pertanian sering dihadapkan pada karakteristik perilaku yang kompleks oleh rumahtangga semi-komersial, yakni sebagian besar rumahtangga di daerah pertanian yang hasil produksinya sebagian untuk dijual dan sebagian lagi untuk konsumsi mereka sendiri. Selain itu, rumahtangga petani membeli beberapa input dan menyediakan tenaga kerja sendiri. Dengan demikian, setiap perubahan dalam kebijakan yang mengatur kegiatan rumahtangga pertanian tidak hanya akan mempengaruhi produksi, tetapi juga konsumsi dan pasokan tenaga kerja. Hubungan-hubungan seperti inilah yang berusaha dicoba untuk dianalisis dalam upaya untuk memodelkan perilaku rumahtangga pertanian.

Pemahaman yang mendalam tentang perilaku ekonomi mikro rumahtangga pertanian penting untuk mengetahui: (i) faktor apa yang menentukan tingkat produksi pertanian dan permintaan untuk input pertanian, (ii) faktor apa yang mengatur konsumsi dan pasokan tenaga kerja, dan (iii) bagaimana perilaku rumahtangga sebagai produsen mempengaruhi perilakunya sebagai konsumen dan pemasok tenaga kerja, dan sebaliknya. Model rumahtangga pertanian dirancang untuk menangkap hubungan ini secara teoritis dan konsisten, sehingga hasil analisis dapat diterapkan secara empiris untuk menjelaskan dampak dari intervensi kebijakan.

Model ini harus memungkinkan analis untuk memeriksa konsekuensi kebijakan dalam menguji pengaruh kebijakan alternatif terhadap kesejahteraan rumahtangga pertanian yang representatif (Singh et al. 1986). Kebijakan alternatif ini diantaranya berupa program bantuan pemerintah atau perlindungn sosial (Taylor and Alderman 2003, Boone et al. 2013). Selain itu, analisis tentang dampak "spillover" dari sebuah kebijakan pada segmen lain dari populasi pedesaan sangat penting untuk tingkat kesejahteraan rumahtangga. Hal ini dapat diukur oleh persentase penduduk miskin di pedesaan yang mengacu pada tingkat pengeluaran rumahtangga perkapita.

Tujuan penelitian adalah:

1. Membangun model ekonomi rumahtangga petani usaha padi penerima PKH yang mengintegrasikan kebijakan pertanian dan program perlindungan sosial, serta indikator kesejahteraan dan kemiskinan.

2. Menganalisis dampak kebijakan pertanian dan program perlindungan sosial terhadap perilaku ekonomi dan kesejahteraan rumahtangga pertanian, serta pengurangan jumlah penduduk miskin rumahtangga petani di Kabupaten Karawang.

\section{LANDASAN TEORI}

\section{Model Dasar Ekonomi Rumahtangga Pertanian}

Model-model ekonomi rumahtangga pertanian pada umumnya menggunakan kerangka pemikiran model ekonomi rumahtangga yang dirumuskan oleh Becker (1965) yang kemudian oleh Singh et al. (1986) dikembangkan menjadi model analisis ekonomi rumahtangga pertanian secara simultan sehingga terbentuk sebuah model dasar baru yang disebut sebagai model ekonomi rumahtangga pertanian (agricultural household model). Model ini mengintegrasikan aktivitas produksi, konsumsi, dan penggunaan tenaga kerja dalam keluarga sebagai satu kesatuan.

Model ekonomi rumahtangga ini menggunakan sejumlah asumsi, yaitu: pertama, kepuasan rumahtangga dalam mengkonsumsi tidak hanya ditentukan oleh barang dan jasa yang diperoleh di pasar, tetapi juga ditentukan oleh berbagai komoditas yang dihasilkan dalam rumahtangga. Kedua, unsur kepuasan tidak hanya barang dan jasa, tetapi termasuk waktu. Ketiga, waktu dan barang atau jasa dapat digunakan sebagai faktor produksi dalam aktivitas produksi rumahtangga. Dan 
keempat, rumahtangga bertindak sebagai produsen sekaligus konsumen.

Singh et al. (1986) menyatakan bahwa utilitas rumahtangga merupakan fungsi dari konsumsi barang yang dihasilkan rumahtangga, konsumsi barang yang dibeli di pasar dan konsumsi waktu santai. Secara matematis dirumuskan sebagai berikut:

$$
\mathrm{U}=\mathrm{U}\left(X_{a}, X_{m}, X_{l}\right)
$$

dimana:

$X_{a}=$ konsumsi barang yang dihasilkan rumahtangga

$X_{m}=$ konsumsi barang yang dibeli di pasar

$X_{l}=$ konsumsi waktu santai

Pada model Becker dalam

memaksimumkan kepuasaannya rumahtangga dihadapkan pada kendala pendapatan dan waktu, namun pada model yang dikembangkan oleh Singh et al. tidak hanya dihadapkan pada kedua kendala tersebut, tetapi juga memasukan kendala produksi dalam model. Kendala-kendala tersebut berturut-turut mulai dari kendala pendapatan, alokasi waktu dan produksi, sebagai berikut:

$p_{m} X_{m}=p_{a}\left(Q-X_{a}\right)-w(L-F)$

$X_{l}+F=T$

$Q=Q(L, A)$

dimana:

$p_{m} \quad=$ harga barang yang dibeli di pasar

$p_{a}=$ harga barang yang dihasilkan rumahtangga

$\left(Q-X_{a}\right)=$ surplus produksi yang akan dipasarkan (marketed suplus)

$w \quad=$ upah

$L \quad=$ total input tenaga kerja usahatani

$F \quad=$ input tenaga kerja rumahtangga

$T=$ total waktu rumahtangga

$A \quad=$ jumlah faktor produksi tetap (lahan)

Dari persamaan (2), apabila unsur (L-F) positif berarti rumahtangga menyewa tenaga kerja luar keluarga, sebaliknya jika (L-F) negatif berarti rumahtangga menawarkan tenaga kerja ke luar rumahtangga. Ketiga kendala yang dihadapi rumahtangga tersebut dapat disatukan dengan mensubstitusikan kendala waktu (persamaan (3)) dan produksi (persamaan (4)) ke dalam kendala pendapatan (persamaan (2)), sehingga dihasilkan persamaan (5) berikut ini:

$p_{m} X_{m}+p_{a} X_{a}+w X_{l}=w T+\pi$

dimana $\quad \pi=p_{a} Q(L, A)-w L \quad$ adalah keuntungan

Sisi kiri persamaan (5) menunjukkan total pengeluaran rumahtangga untuk barang $\left(X_{m}\right.$ dan $\left.X_{a}\right)$ dan konsumsi waktu $\left(X_{l}\right)$. Sedangkan sisi kanan adalah pengembangan oleh Becker (1965) tentang konsep full income dimana nilai waktu yang tersedia $(w T)$ dicatat secara eksplisit. Singh et al. (1986) memperluas model Becker dengan memasukkan pengukuran tingkat keuntungan usaha $\left(p_{a} Q-w L\right)$ dimana seluruh tenaga kerja dihitung berdasarkan upah pasar.

Persamaan (1) dan (5) menjelaskan bahwa rumahtangga memaksimumkan kepuasannya dalam memilih tingkat konsumsi dari barang yang dibeli di pasar $\left(X_{m}\right)$, barang yang diproduksi oleh rumahtangga $\left(X_{a}\right)$, waktu santai yang dikonsumsi rumahtangga $\left(X_{l}\right)$, dan tenaga kerja yang digunakan dalam kegiatan produksi $(L)$. Kondisi first order condition dengan penggunaan input tenaga kerja dapat diturunkan sebagai berikut:

$$
p_{a} \partial Q / \partial L=w
$$

Persamaan (6) menyatakan nilai produk marginal tenaga kerja (value marginal product of labor $=$ MPL) sama dengan upah atau secara implisit merupakan fungsi penggunaan input tenaga kerja. Oleh karena derivasi yang dilakukan bersifat parsial, maka variabel endogen yang dihasilkan hanya $L$, variabel-variabel lainnya, yaitu $X_{m}, X_{a}$, dan $X_{l}$ tidak muncul karena dianggap tidak mempengaruhi pilihan rumahtangga. Dengan demikian penyelesaian dari kondisi order pertama persamaan (6) menghasilkan penggunaan faktor (tenaga kerja, $L$ ) sebagai fungsi dari upah $(w)$, harga barang yang dihasilkan rumahtangga $\left(p_{a}\right)$, dan faktor tetap (parameter teknologi fungsi produksi atau 
lahan, A). Pemecahan persamaan dapat dinyatakan sebagai:

$$
L^{*}=L^{*}\left(w, p_{a}, A\right)
$$

Jika persamaan (7) disubstitusikan ke dalam sisi sebelah kanan persamaan (5) menghasilkan full income ketika pilihan input tenaga kerja memaksimumkan keuntungan usahatani. Persamaan (5) dapat ditulis menjadi:

$$
p_{m} X_{m}+p_{a} X_{a}+w X_{l}=Y^{*}
$$

dimana $Y^{*}$ adalah nilai pendaptan penuh (full income) terkait perilaku keuntungan maksimum.

Dengan demikian persamaan (8) menjadi kendala baru dalam model, hasil perhitungan first order condition secara berturut-turut terhadap $X_{m}, X_{a}$, dan $X_{l}$ sebagai berikut:

$\partial U / \partial X_{m}=\lambda p_{m}$

$\partial U / \partial X_{a}=\lambda p_{a}$

$\partial U / \partial X_{l}=\lambda p_{w}$

dan

$$
p_{m} X_{m}+p_{a} X_{a}+w X_{l}=Y^{*}
$$

Mengacu pada langkah-langkah dalam penyelesaian persamaan (6), penyelesaian persamaan (9) menghasilkan fungsi penggunaan barang yang dibeli, fungsi barang yang dihasilkan, dan fungsi konsumsi waktu santai berturut-turut sebagai berikut:

$$
\begin{aligned}
& X_{m}=X_{m}\left(p_{m}, p_{a}, w, Y^{*}\right) \\
& X_{a}=X_{a}\left(p_{a}, p_{m}, w, Y^{*}\right) \\
& X_{l}=X_{l}\left(w, p_{m}, p_{a}, Y^{*}\right) . .
\end{aligned}
$$

Dari persamaan (10) sampai (12) dapat dikatakan bahwa jumlah penggunaan (konsumsi) barang yang dibeli, barang hasil sendiri, dan waktu santai merupakan fungsi dari harga barang yang dibeli, harga barang hasil sendiri, upah, dan full income saat keuntungan maksimum.

\section{METODE PENELITIAN}

\section{Jenis Data dan Lokasi Penelitian}

Jenis data yang digunakan dalam tulisan adalah data cross section, diperoleh dari data primer hasil survei lapangan di
Kabupaten Karawang, Provinsi Jawa Barat. Unit penelitian dari survei adalah rumahtangga usahatani padi penerima $\mathrm{PKH}$ dengan jumlah responden sebanyak 139 rumahtangga petani. Penentuan unit penelitian disesuaikan dengan tujuan penelitian yang mengarah kepada gambaran tentang program perlindungan sosial. Waktu penelitian dilaksanakan pada bulan November-Desember 2017. Karakteristik rumahtangga dan kinerja usaha pertanian yang diteliti adalah kondisi pada rentang waktu November 2016 sampai dengan Oktober tahun 2017.

\section{Metode Pengambilan Sampel}

Populasi penelitian adalah rumahtangga petani usaha padi penerima PKH. Sebagaimana petani umumnya, petani ini juga menerima program pertanian (subsidi pupuk dan HPP gabah). Selain itu juga mendapat program perlindungan sosial lainnya (contoh raskin dan KIP).

Metode pengambilan sampel yag digunakan adalah multistage cluster sampling dengan tahapan sebagi berikut:

1. Lokasi penelitian di Kabupaten Karawang ditentukan secara purposive. Pemilihan kabupaten ini karena merupakan wilayah sentra produksi padi dan terdapat rumahtangga penerima program pertanian dan program perlindungan sosial. Selain itu, lokasinya dekat dengan pusat-pusat kegiatan ekonomi dan wilayah perkotaan (Karawang, Jabodetabek, dan Bandung), sehingga dapat memberikan berbagai kesempatan kerja dan diversifikasi pendapatan rumahtangga petani.

2. Penentuan lokasi sampel kecamatan secara purposive yaitu kecamatan Kutawaluya, Tempuran, dan Martapura. Pemilihan kecamatan ini karena merupakan sentra produksi padi dan terdapat rumahtangga penerima program pertanian dan program perlindungan sosial.

3. Penentuan lokasi sampel desa secara random sebesar 60 persen dari jumlah desa pada masing-masing kecamatan terpilih (4 sampai 6 desa). Data jumlah peserta PKH masing-masing desa 
terpilih telah diperoleh dari Direktorat Perlindungan dan Jaminan Sosial, Kementrian Sosial RI. Data tersebut digunakan sebagai kontrol jumlah peserta PKH. Sedangkan database peserta PKH juga diperoleh dari Koordinator PKH Kabupaten Karawang.

Tabel 1 Daftar Populasi dan Sampel Petani padi Penerima PKH, Kabupaten Karawang, 2017

\begin{tabular}{|c|c|c|c|c|c|}
\hline Kecamatan & Desa $(60 \%)$ & $\begin{array}{c}\text { Jumlah } \\
\text { Peserta } \\
\text { PKH }\end{array}$ & $\begin{array}{l}\text { Petani } \\
\text { padi } \\
\text { (Peng- } \\
\text { garap } \\
\text { dan } \\
\text { Buruh) }\end{array}$ & $\begin{array}{c}\text { Popula- } \\
\text { si } \\
\text { Petani } \\
\text { Peng- } \\
\text { garap } \\
\text { PKH }\end{array}$ & $\begin{array}{c}\text { Sampel } \\
(30 \%)\end{array}$ \\
\hline \multirow[t]{4}{*}{ Kutawaluya } & Sindangmukti & 194 & 151 & 42 & 13 \\
\hline & Sindangmulya & 249 & 193 & 28 & 8 \\
\hline & Sindangsari & 308 & 237 & 40 & 13 \\
\hline & Sindangkarya & 188 & 127 & 20 & 6 \\
\hline \multirow[t]{6}{*}{ Rawamerta } & Cibadak & 117 & 92 & 50 & 15 \\
\hline & Gombongsari & 102 & 81 & 54 & 16 \\
\hline & Panyingkiran & 193 & 157 & 42 & 13 \\
\hline & Sekarwangi & 93 & 74 & 40 & 12 \\
\hline & Kutawargi & 160 & 114 & 40 & 12 \\
\hline & Mekarjaya & 120 & 95 & 23 & 7 \\
\hline \multirow[t]{5}{*}{ Tempuran } & Lemahkarya & 186 & 145 & 40 & 13 \\
\hline & Lemahmakmur & 101 & 80 & 31 & 9 \\
\hline & Purwajaya & 152 & 119 & 17 & 5 \\
\hline & Pagadungan & 174 & 116 & 28 & 8 \\
\hline & Lemahduhur & 166 & 130 & 30 & 8 \\
\hline \multicolumn{2}{|c|}{ JUMLAH } & 2,503 & 1,911 & 525 & 158 \\
\hline
\end{tabular}

4. Daftar nama petani padi pada desa terpilih di kecamatan terpilih dari database peserta $\mathrm{PKH}$ yang eligible disusun sebagai kerangka sampling (sampling frame) rumahtangga petani, yakni rumahtangga petani penerima menggarap/memiliki usahatani padi. Berdasarkan kerangka sampling ini diperoleh total rumahtangga usahatani padi penerima $\mathrm{PKH}(\mathrm{N})$.

5. Jumlah rumahtangga sampel ditentukan sebanyak 30 persen dari total rumahtangga usahatani padi penerima PKH. Penentuan ukuran sampel untuk masing-masing desa dilakukan secara proporsional.

6. Unit penelitian rumahtangga diperoleh secara random dan jumlah hasil pengambilan sampel disajikan dalam Tabel 1.

\section{Spesifikasi Model}

Alat yang digunakan untuk menganalisis tujuan penelitian adalah model ekonomi rumahtangga pertanian (agriculture household model). Model ini menggambarkan keterkaitan alur keputusan alokasi sumberdaya untuk menghasilkan output produksi dan alokasi pendapatan pada berbagai jenis pengeluaran rumahtangga pertanian dengan kendala waktu dan anggaran. Model ini menganalisis dampak faktor-faktor internal dan eksternal yang mempengaruhi perilaku ekonomi rumahtangga petani dalam mengalokasikan waktu kerja, pendapatan, pengeluaran konsumsi, dan pengeluaran investasi. Model juga digunakan untuk menganalisis dampak kebijakan dari program-program pemerintah yang terkait dengan rumahtangga pertanian.

Model ekonomi rumahtangga pertanian menggunakan sistem persamaan simultan, sehingga dapat menggambarkan kompleksitas keterkaitan antar variabel ekonomi yang ada pada ekonomi rumahtangga petani. Penggunaan model ekonomi rumahtangga pertanian sangat disarankan oleh Tirivayi et al. (2016) dalam rangka menyusun kerangka pikir dari interaksi kebijakan program perlindungan sosial dan kebijakan pertanian.

Spesifikasi model ekonomi rumah tangga usaha padi penerima PKH adalah sebagai berikut:

\section{Blok produksi dan biaya produksi}

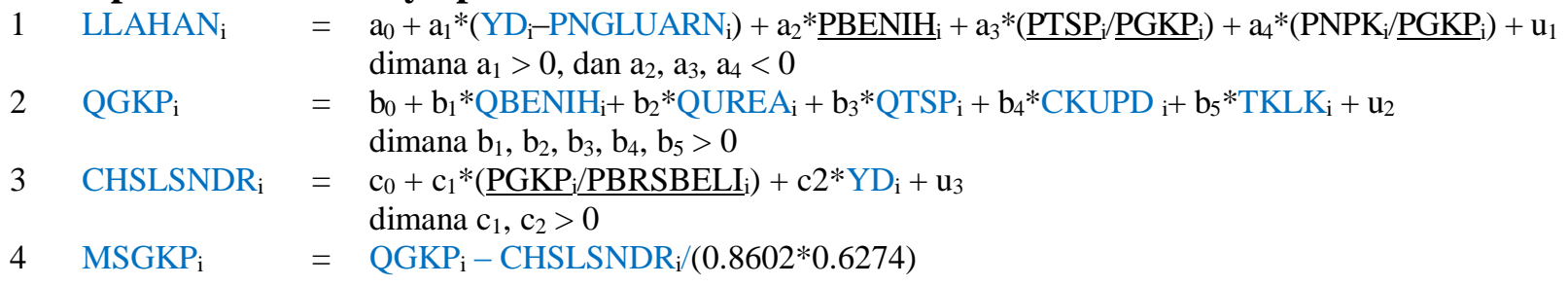




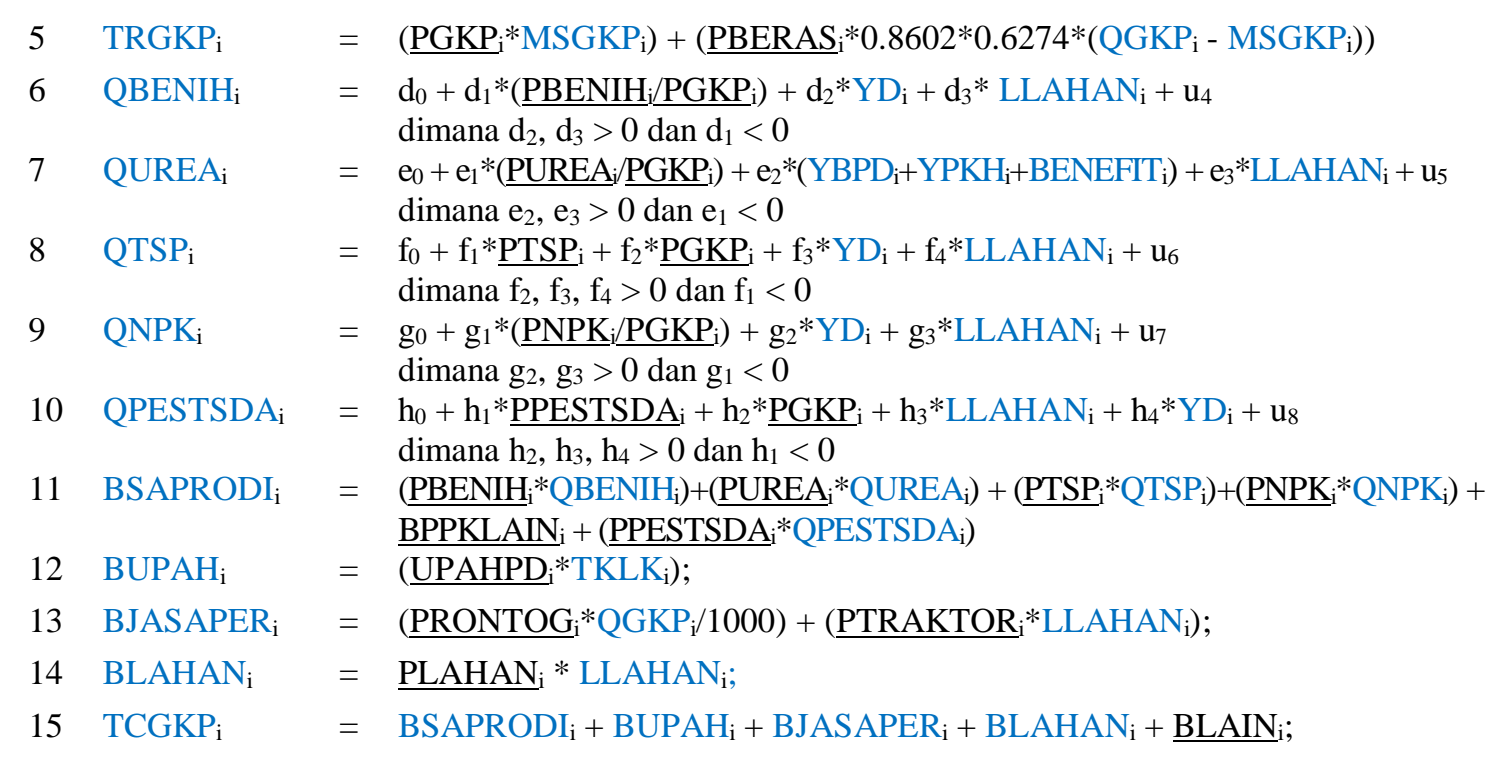

\section{Blok curahan waktu kerja}

Permintaan curahan waktu kerja usaha padi
16 CKUPD $_{\mathrm{i}}$
$=\mathrm{i}_{0}+\mathrm{i}_{1} *$ LLAHAN $_{\mathrm{i}}+\mathrm{i}_{2} *$ TKLK $_{\mathrm{i}}+\mathrm{i}_{3} * \mathrm{CKNP}_{\mathrm{i}}+\mathrm{i}_{4} *$ PNGLUARN $_{\mathrm{i}}+\mathrm{u}_{9}$ dimana $i_{1}, i_{4}>0$ dan $i_{2}, i_{3}<0$
17 TKLK $_{\mathrm{i}}$
$=\mathrm{m}_{0}+\mathrm{m}_{1} *$ LLAHAN $_{\mathrm{i}}+\mathrm{m}_{2} *$ UPAHLK $_{\mathrm{i}}+\mathrm{m}_{3} * \mathrm{CKUPD}_{\mathrm{i}}+\mathrm{u}_{10}$
18 DTK $_{\mathrm{i}}$ dimana $\mathrm{m}_{1}>0$ dan $\mathrm{m}_{2}, \mathrm{~m}_{3}<0$

Penawaran curahan waktu kerja rumah tangga
$19 \mathrm{CKBPD}_{\mathrm{i}}$
$=\mathrm{o}_{0}+\mathrm{o}_{1} * \underline{\text { UPAHPD }}_{\mathrm{i}}+\mathrm{o}_{2} * \mathrm{CKUPD}_{\mathrm{i}}+\mathrm{o}_{3} * \mathrm{CKNP}_{\mathrm{i}}+\mathrm{o}_{4} * \mathrm{PNGLUARN}_{\mathrm{i}}+\mathrm{u}_{11}$ dimana $\mathrm{o}_{1}, \mathrm{o}_{2},>0$, dan $\mathrm{O}_{3}, \mathrm{o}_{4}<0$
$20 \mathrm{CKNP}_{\mathrm{i}}$
$=\mathrm{s} 0+\mathrm{s} 1 * \mathrm{CKUPD}_{\mathrm{i}}+\mathrm{s} 2 * \mathrm{CKBPD}_{\mathrm{i}}+\mathrm{s} 3 * \mathrm{PNGLUARN}_{\mathrm{i}}+\mathrm{u} 12$ dimana $\mathrm{s} 3>0$ dan s1, s2 $<0$
$21 \mathrm{STK}_{\mathrm{i}}$
$=$ CKUPD $_{\mathrm{i}}+\mathrm{CKBPD}_{\mathrm{i}}+\underline{\mathrm{CKPT}}_{\mathrm{i}}+\mathrm{CKNP}_{\mathrm{i}}$;

\section{Blok pendapatan rumahtangga}

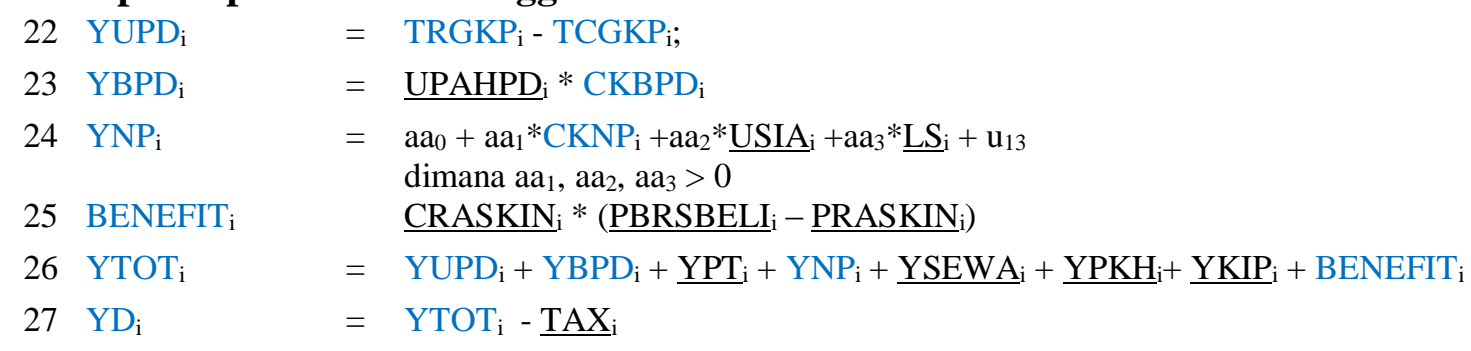

\section{Blok Pengeluararan dan kesejahteraan rumahtangga}

Pengeluaran konsumsi rumahtangga
28 CBRSBLI $_{\mathrm{i}}$
$=\mathrm{af}_{0}+\mathrm{af}_{1} * \underline{\text { PBRSBELI }_{i}}+\mathrm{af}_{2} * \mathrm{YD}_{\mathrm{i}}+\mathrm{af}_{3} * \underline{\mathrm{JART}}_{\mathrm{i}}+\mathrm{u}_{14}$ dimana af $3>0$ dan af $f_{1}$, af $_{2}<0$
29 CBERAS $_{\mathrm{i}}$ $=$ CHSLSNDR $_{\mathrm{i}}+\mathrm{CBRSBLI}_{\mathrm{i}}$
30 NKBERAS $_{\mathrm{i}}$
$=\left(\underline{\text { PBRSBELI }}_{i} *\right.$ CBRSBLI $\left._{\mathrm{i}}\right)+\left(\underline{\text { PBERAS }}_{i} * \mathrm{CHSLSNDR}_{\mathrm{i}}\right)+$
31 NKPANONB $_{\mathrm{i}}$
$=\mathrm{ag}_{0}+\mathrm{ag}_{1} * \mathrm{YD}_{\mathrm{i}}+\mathrm{ag}_{2} * \mathrm{INVSDM}_{\mathrm{i}}+\mathrm{u}_{15}$ dimana $\mathrm{ag}_{1}>0$ dan $\mathrm{ag}_{2}<0$
32 NKPANGAN
$=$ NKBERAS $_{\mathrm{i}}+$ NKPANONB $_{\mathrm{i}}$
$33 \mathrm{NKNON}_{\mathrm{i}}$
$=\mathrm{ah}_{0}+\mathrm{ah}_{1} * \mathrm{YD}_{\mathrm{i}}+\mathrm{ah}_{2} * \mathrm{INVSDM}_{\mathrm{i}}+\mathrm{u}_{16}$ dimana $a h_{1}>0$ dan $\mathrm{ah}_{2}<0$
34 NKTOT $_{\mathrm{i}}$
$=$ NKPANGAN $_{\mathrm{i}}+\mathrm{NKNON}_{\mathrm{i}}$; 
Pengeluaran investasi SDM rumahtangga

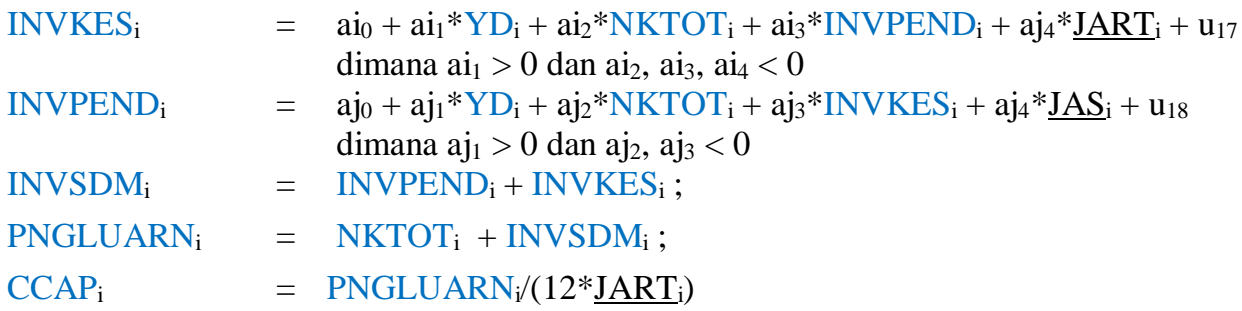

Jika CCAP $\mathrm{C}_{\mathrm{i}}>\mathrm{GK}$, maka $\mathrm{RTM}_{\mathrm{i}}=0$

(non rumahtangga miskin) dan

jika $\mathrm{CCAP}_{\mathrm{i}} \leq \mathrm{GK}$, maka $\mathrm{RTM}_{\mathrm{i}}=1$ (rumahtangga miskin).

Garis kemiskinan (GK) Kabupaten Karawang adalah 408.579 rupiah/kapita/bulan (BPS 2017) sehingga persentasi penduduk miskin (PPM):

40. $\mathrm{PPM}=\left\{\sum_{1}^{\mathrm{n}}\left(\mathrm{RTM}_{\mathrm{i}} * \mathrm{JART}_{\mathrm{i}}\right) / \sum_{\mathrm{i}}^{\mathrm{n}} \mathrm{JART}_{\mathrm{i}}\right\} * 100 \%$; $\mathrm{i}=$ rumahtangga ke-i $(1,2, \ldots \ldots, \mathrm{n})$

\section{Label Variabel Endogen}

\section{CKUPD}

2 TKLK

4 CKBPD

5 CKNP

6 STK

7 LLAHAN

8 QGKP

9 TRGKP

10 QBENIH

11 QUREA

12 QTSP

13 QNPK

14 QPESTSDA = Permintaan pupuk pestisida

15 BSAPRODI = Biaya penggunaan benih,

16 BUPAH $(\mathrm{Kg})$ pupuk, dan pestisida ( $\mathrm{Rp}$ 000)

$=$ Jumlah curahan kerja art pada usaha padi (HOK)

$=$ Jumlah penggunaan waktu kerja luar pada usaha padi (HOK)

$=$ Total permintaan waktu kerja pada usaha Padi (HOK)

$=$ Jumlah curahan waktu kerja ART buruh tani padi (HOK)

$=$ Jumlah curahan waktu kerja ART sektor non pertanian (HOK)

$=$ Total penawaran kerja anggota rumahtangga (HOK)

$=$ Luas lahan garapan $(\mathrm{M} 2)$

$=$ Produksi GKP $(\mathrm{Kg})$

$=$ Total pendapatan $($ total revenue) usaha padi ( $\mathrm{Rp}$ 000)

$=$ Permintaan benih $(\mathrm{Kg})$

$=$ Permintaan pupuk urea $(\mathrm{Kg})$

$=$ Permintaan pupuk TSP $(\mathrm{Kg})$

$=$ Permintaan pupuk NPK $(\mathrm{Kg})$

= Biaya upah pekerja luar keluarga (Rp 000)
17 BJASAPER = Nilai biayajasa pertanian (Rp 000)

18 BLAHAN = Nilai biaya sewa lahan $(\mathrm{Rp}$ 000)

19 TCGKP $=$ Total biaya $($ total cost $)$ usaha padi (Rp 000)

20 YUPD $=$ Pendapatan rumahtangga pada usaha padi (Rp 000)

$21 \mathrm{YBPD}=$ Pendapatan rumahtangga sebagai buruh padi (Rp 000)

22 YNP

$=$ Pendapatan rumahtangga pada non pertanian $(\mathrm{Rp}$ 000)

23 BENEFIT = Pendapatan dari selisih raskin dan harga pasar ( $\mathrm{Rp}$ 000)

$24 \mathrm{YD}=$ Pendapatan disposibel rumahtangga $(\operatorname{Rp} 000))$

$25 \mathrm{CBRSBLI}=$ Konsumsi beras dari Pembelian (Kg)

26 CHSLSNDR = Konsumsi beras dari Hasil Sendiri $(\mathrm{Kg})$

27 CBERAS $=$ Total konsumsi beras $(\mathrm{Kg})$

28 NKBERAS $=$ Nilai konsumsi beras $(\mathrm{Rp}$ 000)

29 NKPANONB $=$ Nilai konsumsi pangan non beras ( Rp 000)

30 NKNON= Nilai konsumsi non pangan (Rp 000)

31 NKTOT = Total nilai konsumsi $(\mathrm{Rp}$ 000)

32 INVKES $=$ Nilai investasi kesehatan (Rp 000)

33 INVPEND $=$ Nilai investasi pendidikan (Rp 000)

34 INVSDM = Total nilai investasi sumber daya manusia $(\operatorname{Rp} 000)$

35 PNGLUARN = Total pengeluaran $(\operatorname{Rp} 000)$

36 MSGKP $=$ Marketed surplus $(\mathrm{Rp} 000)$

37 YTOT $=$ Total pendapatan rumahtangga $(\operatorname{Rp} 000)$

38 NKPANGAN $=$ Total nilai konsumsi pangan (Rp 000)

39 CCAP $=$ Pengeluaran perkapita rumahtangga perbulan $(\mathrm{Rp}$ 000)

$40 \mathrm{PPM}=$ Persentase penduduk miskin $(\%)$ 


\section{Label Variabel Eksogen}

\begin{tabular}{|c|c|c|}
\hline BLAIN & $=$ & $\begin{array}{l}\text { Nilai biaya lain-lain } \\
\text { (Rp/musim tanam) }\end{array}$ \\
\hline BPPKLAIN & $=$ & $\begin{array}{l}\text { Nilai biaya pupuk lainnya } \\
\text { (Rp/musim tanam) }\end{array}$ \\
\hline JART & $=$ & $\begin{array}{l}\text { Jumlah anggota } \\
\text { rumahtangga (Orang) }\end{array}$ \\
\hline JAS & $=$ & $\begin{array}{l}\text { Jumlah anggota } \\
\text { rumahtangga masih } \\
\text { Sekolah (Orang) }\end{array}$ \\
\hline $\mathrm{k} 1=0.8602$ & $=$ & $\begin{array}{l}\text { Kooefesien susut konversi } \\
\text { dari GKP ke GKG }\end{array}$ \\
\hline $\mathrm{k} 2=0.6274$ & $=$ & $\begin{array}{l}\text { Kooefesien susut konversi } \\
\text { dari GKG ke BERAS }\end{array}$ \\
\hline LS & $=$ & $\begin{array}{l}\text { Rata-rata lama Sekolah } \\
\text { (Tahun) }\end{array}$ \\
\hline PBENIH & $=$ & Harga benih $(\mathrm{Rp} / \mathrm{Kg})$ \\
\hline PBRSBELI & $=$ & $\begin{array}{l}\text { Harga beras yang dibeli } \\
(\mathrm{Rp} / \mathrm{Kg})\end{array}$ \\
\hline PLAHAN & $=$ & $\begin{array}{l}\text { Hraga sewa lahan } \\
\text { (Rp/M2) }\end{array}$ \\
\hline PPESTSDA & $=$ & Harga pestisida $(\mathrm{Rp} / \mathrm{Kg})$ \\
\hline PRONTOG & $=$ & $\begin{array}{l}\text { Harga jasa rontok Gabah } \\
\text { (Rp / Ton) }\end{array}$ \\
\hline PTRAKTOR & $=$ & $\begin{array}{l}\text { Harga jasa pengunaan } \\
\text { traktor }(\mathrm{Rp} / \mathrm{Ha})\end{array}$ \\
\hline PGKP & $=$ & Harga transaksi GKP \\
\hline PUREA & $=$ & $\begin{array}{l}\text { Harga transaksi eceran } \\
\text { pupuk UREA }\end{array}$ \\
\hline PTSP & $=$ & $\begin{array}{l}\text { Harga transaksi eceran } \\
\text { pupuk TSP }\end{array}$ \\
\hline PNPK & $=$ & $\begin{array}{l}\text { Harga transaksi eceran } \\
\text { pupuk NPK }\end{array}$ \\
\hline TAX & $=$ & $\begin{array}{l}\text { Biaya pajak, iuran, dan } \\
\text { pungutan sejenis lainnya } \\
\text { (Rp/tahun) }\end{array}$ \\
\hline UPAHPD & $=$ & $\begin{array}{l}\text { Tingkat upah tenaga kerja } \\
\text { di sektor padi }(\mathrm{Rp} / \mathrm{HOK})\end{array}$ \\
\hline USIA & $=$ & $\begin{array}{l}\text { Rata-rata usia anggota } \\
\text { rumahtangga (tahun) }\end{array}$ \\
\hline YKIP & $=$ & $\begin{array}{l}\text { Pendapatan rumahtangga } \\
\text { bersumber dari batuan lain } \\
\text { (Rp/tahun) }\end{array}$ \\
\hline YPKH & $=$ & $\begin{array}{l}\text { Pendapatan rumahtangga } \\
\text { bersumber dari PKH } \\
\text { (Rp/tahun) }\end{array}$ \\
\hline YPT & $=$ & $\begin{array}{l}\text { Pendapatan rumahtangga } \\
\text { usaha pertanian selain } \\
\text { padi (Rp/tahun) }\end{array}$ \\
\hline YSEWA & $=$ & $\begin{array}{l}\text { Pendapatan yang berasal } \\
\text { dari kepemilikan } \\
\text { (Rp/tahun) }\end{array}$ \\
\hline
\end{tabular}

\section{Identifikasi dan Estimasi Model}

Suatu model persamaan simultan harus teridentifikasi agar adapat dilakukan estimasi parameter (Koutsoyiannis 1977). Rumus identifikasi berdasarkan order condition adalah: $(\mathrm{K}-\mathrm{M}) \geq(\mathrm{G}-1)$ dimana: $\mathrm{K}=$ total peubah dalam model (peubah endogen dan predeterminan), $\mathrm{M}=$ jumlah peubah endogen dan eksogen yang dimasukkan dalam suatu persamaan tertentu dalam model, dan $\mathrm{G}=$ total persamaan dalam model, yaitu peubah endogen dalam model. Jika suatu persamaan dalam model menunjukkan kondisi $(\mathrm{K}-\mathrm{M})>(\mathrm{G}-1)$ maka persamaan tersebut dinyatakan terindentifikasi berlebih (over identified); jika menunjukkan kondisi $(\mathrm{K}-\mathrm{M})=(\mathrm{G}-1)$, maka persamaan tersebut terindentifikasi secara tepat (exactly identified); sedangkan jika menunjukkan kondisi $(\mathrm{K}-\mathrm{M})<(\mathrm{G}-1)$, maka persamaan tersebut tidak terindentifikasi (unidentified).

Model rumahtangga pertanian yang dibangun memiliki 40 persamaan, yang terdiri dari 18 persamaan struktural dan 22 persamaan identitas dengan 40 peubah endogen, 24 peubah eksogen. Berdasarkan kriteria "order condition" setiap persamaan pada kedua model di atas adalah "over identified". Estimasi parameter dilakukan dengan metode 2SLS (two stage least squares). Selanjutnya dianalisis berdasarkan: (1) nilai statistik uji-t (dengan taraf $\alpha=15$ persen), (2) nilai statistik uji-F, dan (3) nilai koefisien determinasi $\left(\mathrm{R}^{2}\right)$. Disamping itu juga dilihat respon peubah endogen terhadap perubahan peubah penjelas.

\section{Simulasi Model}

Setelah model divalidasi dan memenuhi kriteria statistik yang diinginkan, maka model dapat digunakan untuk simulasi dalam menganalisis dampak kebijakan terhadap varibel endogen. Simulasi yang dilakukan adalah:

S1. Peningkatan Harga pupuk Urea, TSP, dan NPK, masing-masing sebesar 20 persen. Simulasi ini berdasarkan pada histori kenaikan HET pupuk urea sejak tahun 2006 hingga tahun 2012 denga rata-rata sebesar 20 persen.

S2. Peningkatan HPP Gabah sebesar 10 persen. Simulasi ini berdasarkan pada fleksibilitas harga serapan gabah Bulog terkait Inpres No.5/2015 tentang Harga Pokok Pembelian gabah/beras. Fleksibilitas yang dapat 
ditolerir adalah sebesar 10 persen (Kontan 14 September 2018).

S3. Peningkatan nilai transfer tunai PKH 100 persen. Simulasi ini berdasarkan pada wacana atas kenaikan PKH sebesar 100 persen (Kompas, 3 Desember 2018).

S4. Kombinasi simulasi S1 dan S3.

S5. Kombinasi simulasi S2 dan S3.

\section{HASIL DAN PEMBAHASAN}

\section{Keragaan Umum Hasil Estimasi dan Hasil Validasi Model}

Hasil estimasi parameter seluruh variabel dalam model sebagaimana yang disajikan pada Tabel 2 menunjukkan nilai koefisien determinasi bervariasi antara 0.0639 0.9832 , sedangkan nilai statistik $\mathrm{F}$ berkisar antara 4.18-2626,65. Sebanyak 17 dari 18 persamaan dalam model memiliki nilai $\mathrm{F}$ yang nyata pada taraf $\alpha=1$ persen. Adapun 1 persamaan (CHSLSNDR) memiliki nilai $F$ yang nyata pada taraf $\alpha=5$ persen.

Besaran probabilitas nilai $\mathrm{F}$ mengindikasikan bahwa secara bersamasama seluruh variabel penjelas dalam setiap persamaan berpengaruh nyata terhadap variabel endogen, tetapi dengan taraf nyata yang berbeda. Secara umum hasil sebagaimana Tabel 2 memberikan gambaran bahwa variabel-variabel eksogen dalam model perilaku rumahtangga petani hanya mampu menerangkan variasi (keragaman) variabel endogen antara 6.3998.32 persen. Variasi sisanya ditentukan variabel lain yang belum masuk dalam model.

Tabel 2 Hasil Uji F dan Koefisien Determinasi model ekonomi rumahtangga petani usaha padi penerima $\mathrm{PKH}$

\begin{tabular}{lllrrr}
\hline No. & \multicolumn{1}{c}{ Variabel } & \multicolumn{1}{c}{ Persamaan Struktural } & F Value & Pr.> F & \multicolumn{1}{c}{$\mathrm{R}^{2}$} \\
\hline 1. & LLAHAN & Luas lahan garapan (ha) & 4.25 & 0.0028 & 0.11264 \\
2. & QGKP & Produksi padi (kg) & 205.43 & $<.0001$ & 0.88536 \\
3. & QBENIH & Penggunaan benih (kg) & 141.36 & $<.0001$ & 0.75854 \\
4. & QUREA & Penggunaan Urea (kg) & 208.16 & $<.0001$ & 0.82225 \\
5. & QTSP & Penggunaan TSP (kg) & 23.5 & $<.0001$ & 0.41226 \\
6. & QNPK & Penggunaan NPK per M2 (Kg) & 12.82 & $<.0001$ & 0.22168 \\
7. & QPESTSDA & Penggunaan pestisida (kg) & 78.59 & $<.0001$ & 0.70113 \\
8. & CKUPD & Curahan waktu kerja usaha padi rumahtangga (HOK) & 52.73 & $<.0001$ & 0.61153 \\
9. & TKLKL & Penggunaan sewa waktu kerja usaha padi (HOK) & 2626.65 & $<.0001$ & 0.98316 \\
10. & CKBPD & Curahan waktu kerja buruh padi rumahtangga (HOK) & 41.2 & $<.0001$ & 0.55157 \\
11. & CKNP & Curahan waktu usaha non pertanian rumahtangga (HOK) & 28.77 & $<.0001$ & 0.38998 \\
12. & YNP & Pendapatan usaha non pertanian (rp000) & 98.13 & $<.0001$ & 0.68561 \\
13. & CHSLSNDR & Permintaan beras hasil sendiri (kg) & 4.64 & 0.0113 & 0.06385 \\
14. & CBRSBLI & Permintaan beras yang dibeli (Kg) & 22.3 & $<.0001$ & 0.33131 \\
15. & NKPANONB & Nilai konsunsi pangan non beras (Rp000) & 39.38 & $<.0001$ & 0.36673 \\
16. & NKNON & Nilai konsunsi non pangan (Rp000) & 36.12 & $<.0001$ & 0.3469 \\
17. & INVKES & Investasi rumahtangga untuk Kesehatan (Rp000) & 4.18 & 0.0032 & 0.11092 \\
18. & INVPEND & Investasi rumahtangga untuk pendidikan (Rp000) & 12.52 & $<.0001$ & 0.2721 \\
\hline
\end{tabular}

Pada kriteria statistik idealnya setiap persamaan memiliki nilai koefisien determinasi yang tinggi dan standar error estimasi parameter yang kecil, tetapi kenyataannya sulit untuk memenuhi kedua kriteria tersebut sekaligus. Jika kriteria statistik ini tidak dapat dipenuhi, maka kriteria yang perlu dipertahankan adalah kriteria ekonomi, yaitu memperhatikan arah (sign) dan besaran (magnitude) parameter yang diestimasi (Koutsoyiannis 1977). Tujuan model adalah untuk menjelaskan perilaku, maka persamaan mengutamakan standar error terkecil. Selain itu, menurut Pyndick dan Rubinfield (1998), pada penggunaan data cross section, perolehan nilai koefisien determinasi yang rendah tidak dapat dihindarkan. Selain faktor data, koefisien determinasi rendah juga bisa diakibatkan oleh spesifikasi model yang belum optimal. Dengan demikian, dapat dikatakan bahwa hasil estimasi model yang berguna untuk menganalisis faktor-faktor yang mempengaruhi perilaku ekonomi rumah tangga petani penerima $\mathrm{PKH}$ adalah layak. 
Tabel 3 Hasil validasi model ekonomi rumahtangga usaha padi penerima PKH

\begin{tabular}{|c|c|c|c|c|c|}
\hline \multirow{2}{*}{ No } & \multirow{2}{*}{ Variabel Endogen } & \multicolumn{3}{|c|}{ Kesalahan } & \multirow{2}{*}{ U-Theil } \\
\hline & & UM & US & $\mathrm{UC}$ & \\
\hline 1 & LLAHAN & 0.0000 & 0.1700 & 0.8300 & 0.3397 \\
\hline 2 & QGKP & 0.0000 & 0.1500 & 0.8500 & 0.3570 \\
\hline 3 & MSGKP & 0.0000 & 0.1500 & 0.8500 & 0.3539 \\
\hline 4 & TRGKP & 0.0000 & 0.1200 & 0.8800 & 0.3504 \\
\hline 5 & QBENIH & 0.0000 & 0.2000 & 0.8000 & 0.3462 \\
\hline 6 & QUREA & 0.0000 & 0.2100 & 0.7900 & 0.3251 \\
\hline 7 & QTSP & 0.0100 & 0.1900 & 0.8100 & 0.4003 \\
\hline 8 & QNPK & 0.0000 & 0.2700 & 0.7300 & 0.5317 \\
\hline 9 & QPESTSDA & 0.0000 & 0.2100 & 0.7900 & 0.3558 \\
\hline 10 & BSAPRODI & 0.0000 & 0.1300 & 0.8700 & 0.3407 \\
\hline 11 & BUPAH & . & . & . & 0.0000 \\
\hline 12 & BJASAPER & 0.0000 & 0.1500 & 0.8500 & 0.3455 \\
\hline 13 & BLAHAN & 0.0000 & 0.1100 & 0.8900 & 0.3196 \\
\hline 14 & TCGKP & 0.0000 & 0.4400 & 0.5600 & 0.2165 \\
\hline 15 & CKUPD & 0.0000 & 0.1900 & 0.8100 & 0.2744 \\
\hline 16 & TKLK & 0.0000 & 0.1900 & 0.8100 & 0.3528 \\
\hline 17 & DTK & 0.0000 & 0.1600 & 0.8400 & 0.3110 \\
\hline 18 & CKBPD & 0.0000 & 0.1300 & 0.8700 & 0.2559 \\
\hline 19 & CKNP & 0.0100 & 0.0500 & 0.9500 & 0.4101 \\
\hline 20 & STK & 0.0100 & 0.1200 & 0.8700 & 0.2722 \\
\hline 21 & YUPD & 0.0000 & 0.0500 & 0.9400 & 0.5636 \\
\hline 22 & YBPD & 0.0000 & 0.1500 & 0.8500 & 0.2543 \\
\hline 23 & YNP & 0.0100 & 0.0400 & 0.9500 & 0.4259 \\
\hline 24 & BENEFIT & & & & 0.0000 \\
\hline 25 & YTOT & 0.0100 & 0.1400 & 0.8500 & 0.3118 \\
\hline 26 & YD & 0.0100 & 0.1400 & 0.8500 & 0.3118 \\
\hline 27 & CHSLSNDR & 0.0000 & 0.1600 & 0.8300 & 0.5809 \\
\hline 28 & CBRSBLI & 0.0300 & 0.2600 & 0.7100 & 0.1816 \\
\hline 29 & CBERAS & 0.0500 & 0.0000 & 0.9500 & 0.1416 \\
\hline 30 & NKBERAS & 0.0400 & 0.0000 & 0.9600 & 0.1577 \\
\hline 31 & NKPANONB & 0.0100 & 0.0000 & 0.9900 & 0.3364 \\
\hline 32 & NKPANGAN & 0.0100 & 0.0200 & 0.9700 & 0.2790 \\
\hline 33 & NKNON & 0.0100 & 0.0100 & 0.9900 & 0.2341 \\
\hline 34 & NKTOT & 0.0100 & 0.0500 & 0.9400 & 0.2501 \\
\hline 35 & INVKES & 0.0000 & 0.1200 & 0.8800 & 0.6533 \\
\hline 36 & INVPEND & 0.0000 & 0.0200 & 0.9800 & 0.4441 \\
\hline 37 & INVSDM & 0.0000 & 0.0000 & 1.0000 & 0.4602 \\
\hline 38 & PNGLUARN & 0.0100 & 0.0800 & 0.9100 & 0.2774 \\
\hline 39 & CCAP & 0.0100 & 0.1900 & 0.8000 & 0.2967 \\
\hline 40 & KEMISKINAN & . & . & . & 0.0000 \\
\hline
\end{tabular}

Terkait dengan hasil validasi model, sebelum membahas dampak perubahanperubahan simulasi kebijakan, maka sangat perlu untuk menguji keandalan (robustness) model dalam mengungkap fenomena yang menjadi fokus analisis melalui prediksi terhadap nilai-nilai aktual variabel endogen. Dengan demikian, terlebih dulu dikemukakan hasil validasi model untuk melihat keeratan dan keragaman nilai hasil prediksi (predicted value) dengan nilai aktual variabel endogen. Model dapat dikatakan baik apabila dapat merepresentasikan fenomena di dunia nyata, sehingga validasi model seharusnya menghasilkan nilai-nilai prediksi yang makin mendekati nilai aktualnya. Selisih antara nilai prediksi dengan nilai aktual menunjukan ukuran error (Pindyck dan Rubenfield, 1998). Terdapat beberapa ukuran error yang umum digunakan sebagai petunjuk mengevaluasi bagaimana kecenderungan antar variabel saling berpengaruh (Pindyck dan Rubienfield, 1998). Sebagian besar penggunaan simultan econometrics, kriteria yang dipilih adalah root mean square percent error (RMSPE) dan statistik U-Theil. Tulisan ini hanya 
membahas kriteria U-Theil untuk melihat kelayakan model. Nilai U-Theil secara umum mendekati nol menunjukkan bahwa model cukup baik digunakan untuk simulasi (Pindyck dan Rubenfield, 1998).

Hasil validasi model melalui penggunaan kriteria $U$-Theil sebagaimana Tabel 3, diketahui bahwa dari 40 persamaan pada model 37 persamaan dapat dihitung nilainya yang berkisar antara 0.1416 dan 0.6533. Pada 37 persamaan tersebut yang mempunyai nilai kurang dari 0.5 sebanyak 33 persamaan (89.18 persen) dan sisanya mempunyai nilai kurang dari 0.5 .
Selanjutnya hasil validasi dekomposisi UTheil pada rumahtangga hanya diperoleh 3 variabel yang memiliki nilai $U_{m}$ di atas 0.1 . Adapun untuk nilai Us, hanya terdapat 6 variabel endogen yang memiliki nilai di atas 0.5 dan terdapat 4 variabel endogen yang memiliki nilai $U_{c}$ di bawah 0.5 .

Dari hasil penilaian keseluruhan validasi di atas secara umum menunjukkan bahwa nilai prediksi variabel endogen pada model cukup dekat dengan nilai aktual, maka dapat dikatakan bahwa model layak digunakan untuk melakukan simulasi.

Tabel 4 Hasil Simulasi Peningkatan HET Pupuk 20 persen dan PKH 100 persen

\begin{tabular}{|c|c|c|c|c|c|c|}
\hline No. & Variabel & Satuan & $\begin{array}{l}\text { Nilai } \\
\text { Basis }\end{array}$ & $\begin{array}{c}\text { S1 } \\
(\% \Delta)\end{array}$ & $\begin{array}{c}\text { S3 } \\
(\% \Delta)\end{array}$ & $\begin{array}{c}\text { S4 } \\
(\% \Delta)\end{array}$ \\
\hline 1 & Luas lahan garapan (2 musim tanam) & $\mathrm{Ha}$ & $13,301.4$ & -11.64 & 4.43 & -7.25 \\
\hline 2 & Produksi gabah kering panen & $\mathrm{Kg}$ & $7,527.5$ & -11.93 & 4.78 & -7.19 \\
\hline 3 & Marketed Surplus & $\mathrm{Kg}$ & $7,367.2$ & -11.95 & 4.58 & -7.40 \\
\hline 4 & Total penerimaan usaha padi & Rp 000 & $36,305.1$ & -11.76 & 4.80 & -7.00 \\
\hline 5 & Penggunaan pupuk Urea & $\mathrm{Kg}$ & 398.6 & -11.14 & 4.94 & -6.25 \\
\hline 6 & Penggunaan pupuk TSP & $\mathrm{Kg}$ & 200.2 & -22.38 & 4.80 & -17.58 \\
\hline 7 & Penggunaan pupuk NPK & $\mathrm{Kg}$ & 103.1 & -16.48 & 9.89 & -6.67 \\
\hline 8 & Biaya Benih, Pupuk, dan Pestisida & Rp 000 & $2,483.1$ & -6.97 & 5.36 & -1.10 \\
\hline 9 & Biaya upah tenaga kerja & $\mathrm{Rp} 000$ & $7,487.8$ & -14.19 & 3.73 & 0.49 \\
\hline 10 & Total biaya usaha padi & $\operatorname{Rp} 000$ & $24,126.2$ & -7.16 & 3.04 & -4.08 \\
\hline 11 & Jumlah curahan kerja ART usaha padi & $\mathrm{HOK}$ & 47.541 & -5.59 & 3.34 & -2.27 \\
\hline 12 & Penggunaan TK luar RT padi & HOK & 103 & -12.32 & 4.47 & -7.94 \\
\hline 13 & Total penggunaan TK usaha padi & HOK & 150.6 & -10.23 & 4.05 & -6.18 \\
\hline 14 & Curahan Waktu Kerja ART Buruh Padi & HOK & 83.1386 & 1.43 & -1.65 & -0.21 \\
\hline 15 & Curahan Waktu Kerja ART Non Pertanian & $\mathrm{HOK}$ & 124.6 & -4.57 & 10.11 & 5.46 \\
\hline 16 & Total penawaran kerja ART & HOK & 257.6 & -2.76 & 4.97 & 2.17 \\
\hline 17 & Pendapatan RT usaha padi & $\mathrm{Rp} 000$ & $12,178.9$ & -20.89 & 8.29 & -12.77 \\
\hline 18 & Pendapatan RT buruh padi & $\operatorname{Rp} 000$ & $6,498.2$ & 0.85 & -1.04 & -0.19 \\
\hline 19 & Pendapatan RT usaha non pertanian & $\operatorname{Rp} 000$ & $7,825.4$ & -4.58 & 10.18 & 5.53 \\
\hline 20 & Total pendapatan RT & $\operatorname{Rp} 000$ & $32,733.8$ & -8.70 & 11.04 & 2.26 \\
\hline 21 & Nilai konsumsi pangan & $\operatorname{Rp} 000$ & 13833 & -6.15 & 7.81 & 1.60 \\
\hline 22 & Nilai konsumsi non pangan & $\operatorname{Rp} 000$ & 8107.2 & -5.91 & 7.51 & 1.54 \\
\hline 23 & Total nilai konsumsi $(21+22)$ & $\operatorname{Rp} 000$ & 21940.2 & -6.06 & 7.70 & 1.58 \\
\hline 24 & Total nilai investasi SDM & $\operatorname{Rp} 000$ & 4652.3 & -11.81 & 14.99 & 3.07 \\
\hline 25 & Total pengeluaran RT $(23+24)$ & $\operatorname{Rp} 000$ & 26592.5 & -7.07 & 8.97 & 1.84 \\
\hline 26 & Pengeluaran perkapita perbulan & $\operatorname{Rp} 000$ & 570.1 & -7.16 & 8.96 & 1.74 \\
\hline 27 & Persentase Penduduk miskin & $\%$ & 30.56 & 7.64 & -2.60 & -0.52 \\
\hline
\end{tabular}

Sumber : data primer 2017, diolah

Keterangan Simulasi S1 $\quad$ : Kenaikan HET pupuk Urea, TSP, dan NPK masing-masing 20 persen

Simulasi S3 : Kenaikan nilai PKH sebesar 100 persen

Simulasi S4 : Kombinasi S1 dan S3

\section{Analisis Dampak Kebijakan}

\section{Simulasi 1: Kenaikan Harga Pupuk Urea,} TSP, dan NPK masing-masing 20 persen

Dampak perubahan harga pupuk dianalisis untuk mengantisipasi perubahan kinerja ekonomi pada rumahtangga petani akibat adanya kebijakan pemerintah berupa pengaturan harga pupuk. Kenaikan harga pupuk merupakan salah satu konsekuensi jika pemerintah menerapkan konsep kebijakan pengurangan secara bertahap (phase-out) subsidi pupuk yakni melalui mekanisme kenaikan HET pupuk. Kenaikan tersebut dilakukan secara bertahap sampai pada tingkat tertentu, 
sehingga harga pupuk masih tetap bersubsidi. Analisis dampak kebijakan kenaikan HET pupuk disimulasikan dengan kenaikan harga Urea, TSP, dan NPK masing-masing 20 persen. Hasil simulasi ditampilkan pada Tabel 4 (kolom S1) yang menunjukkan bahwa seluruh variabel kinerja ekonomi rumahtangga mengalami penurunan.

Peningkatan harga pupuk secara langsung berpengaruh pada permintaan masing-masing pupuk dan memberikan arah yang sesuai dengan hipotesa. Semakin tinggi harga pupuk, permintaan pupuk akan semakin rendah. Permintaan pupuk yang menurun menyebabkan penurunan penggunaan pupuk tersebut di kegiatan usahatani. Disamping itu, hasil simulasi pada model menunjukkan bahwa peningkatan harga menyebabkan proses produksi di usahatani padi mengalami realokasi penggunaan input pupuk yaitu adanya substitusi penggunaan pupuk Urea dengan pupuk TSP.

Penurunan penggunaan pupuk dalam simulasi model berdampak pada menurunnya produksi GKP. Pada kondisi harga output yang sama, penurunan produksi GKP mengakibatkan turunnya total penerimaan usaha padi. Di sisi lain, kenaikan harga pupuk menyebabkan total biaya produksi semakin meningkat. Dengan demikian, keuntungan atau pendapatan usaha padi menjadi turun dan berefek kepada menurunnya total pendapatan rumahtangga. Penurunan total pendapatan rumahtangga selanjutnya berakibat menurunnya seluruh nilai pengeluaran rumahtangga baik konsumsi maupun investasi. Total pengeluaran rumahtangga yang disebut sebagai tingkat kesejahteraan, dalam hal ini berkurang.

Secara struktural, tingkat pengeluaran rumahtangga berpengaruh langsung terhadap curahan waktu kerja di seluruh sektor baik berstatus usaha maupun berstatus sebagai pekerja, termasuk juga waktu kerja yang berasal dari luar rumahtangga. Peningkatan harga pupuk yang berakibat pada menurunnya tingkat pengeluaran rumahtangga juga berdampak terhadap penurunan curahan waktu kerja pada usahatani padi maupun non usahtani padi, sehingga secara total berdampak terhadap penurunan tingkat penawaran kerja (demand labour). Hal ini kembali ikut mendorong penurunan tingkat pendapatan.

Beberapa uraian di atas sejalan dengan penelitian Kusnadi (2005), bahwa efek kenaikan harga pupuk pada rumahtangga petani sangat ditentukan oleh struktur permintaan setiap jenis pupuk. Rusastra (2016), menjelaskan bahwa upaya pengurangan subsidi berdampak pada penggunaan pupuk yang relatif lebih berimbang, yakni penggunaan urea dan TSP mengalami penurunan, sedangkan pupuk lainnya penggunannya meningkat. Peningkatan penggunaan pupuk lainnya disebabkan oleh dampak perubahan harga sendiri yang lebih kecil dibandingkan dengan efek substitusinya sebagai akibat perubahan harga pupuk khususnya urea. Selain itu, dengan menggunakan model dinamis, Komarek et al. (2017) menemukan hal yang sama bahwa terdapat hubungan negatif antara harga pupuk dan penggunaan pupuk, lahan garapan, dan pendapatan.

Pada simulasi ini pengeluaran perkapita menurun sebesar 7.16 persen menjadi 529.300 rupiah, sehingga jika dibandingkan dengan garis kemiskinan Kabupaten Karawang sebesar 408.576 rupiah jumlah penduduk miskin pada kelompok rumahtangga usaha padi penerima $\mathrm{PKH}$ meningkat 7,64 persen yang semula sebesar 30.56 persen menjadi 38,19 persen.

\section{Simulasi 2: Kenaikan HPP gabah-beras sebesar 10 persen}

Salah satu kebijakan pertanian yang sering dilakukan pemerintah adalah mengintervensi pasar dengan menentukan harga output produksi. Harga gabah juga tidak lepas dari kebijakan pemerintah melalui mekanisme penetapan harga pembelian pemerintah (HPP) beras dan gabah Kebijakan ini akan mempengaruhi harga GKP di tingkat petani. Menurut Putri et al. (2013), peningkatan HPP GKP akan memberikan besaran yang sama terhadap besaran perubahan harga transaksi gabah di tingkat petani. Dalam penelitian, kebijakan 
HPP dinaikkan sedemikian rupa sehingga harga gabah meningkat sebesar 10 persen. Hasil simulasi dampak kebijakan sebagaimana ditampilkan pada Tabel 5 (kolom S2).

Tabel 5 Hasil Simulasi Peningkatan HPP Gabah 10 persen dan PKH 100 persen

\begin{tabular}{|c|c|c|c|c|c|c|}
\hline No. & Variabel & Satuan & $\begin{array}{l}\text { Nilai } \\
\text { Basis }\end{array}$ & $\begin{array}{c}\text { S2 } \\
(\% \Delta)\end{array}$ & $\begin{array}{c}\text { S3 } \\
(\% \Delta)\end{array}$ & $\begin{array}{c}\text { S5 } \\
(\% \Delta)\end{array}$ \\
\hline 1 & Luas lahan garapan (2 musim tanam) & $\mathrm{Ha}$ & $13,301.4$ & 16.67 & 4.43 & -1.60 \\
\hline 2 & Produksi gabah kering panen & $\mathrm{Kg}$ & $7,527.5$ & 17.94 & 4.78 & -1.96 \\
\hline 3 & Marketed Surplus & $\mathrm{Kg}$ & $7,367.2$ & 17.62 & 4.58 & -2.03 \\
\hline 4 & Total penerimaan usaha padi & Rp 000 & $36,305.1$ & 29.41 & 4.80 & -2.02 \\
\hline 5 & Penggunaan pupuk Urea & $\mathrm{Kg}$ & 398.6 & 15.20 & 4.94 & -1.48 \\
\hline 6 & Penggunaan pupuk TSP & $\mathrm{Kg}$ & 200.2 & 27.97 & 4.80 & -1.25 \\
\hline 7 & Penggunaan pupuk NPK & $\mathrm{Kg}$ & 103.1 & 31.72 & 9.89 & -0.87 \\
\hline 8 & Biaya Benih, Pupuk, dan Pestisida & $\operatorname{Rp} 000$ & $2,483.1$ & 23.87 & 5.36 & -1.14 \\
\hline 9 & Biaya upah tenaga kerja & $\operatorname{Rp} 000$ & $7,487.8$ & 14.37 & 3.73 & 18.39 \\
\hline 10 & Total biaya usaha padi & $\operatorname{Rp} 000$ & $24,126.2$ & 11.59 & 3.04 & 0.06 \\
\hline 11 & Jumlah curahan kerja ART usaha padi & HOK & 47.541 & 10.73 & 3.34 & -2.06 \\
\hline 12 & Penggunaan TK luar RT padi & HOK & 103 & 17.09 & 4.47 & -1.36 \\
\hline 13 & Total penggunaan TK usaha padi & HOK & 150.6 & 15.01 & 4.05 & -1.66 \\
\hline 14 & Curahan Waktu Kerja ART Buruh Padi & HOK & 83.1386 & -4.52 & -1.65 & -1.88 \\
\hline 15 & Curahan Waktu Kerja ART Non Pertanian & $\mathrm{HOK}$ & 124.6 & 25.20 & 10.11 & 20.00 \\
\hline 16 & Total penawaran kerja ART & $\mathrm{HOK}$ & 257.6 & 12.73 & 4.97 & 6.83 \\
\hline 17 & Pendapatan RT usaha padi & $\operatorname{Rp} 000$ & $12,178.9$ & 64.72 & 8.29 & -6.14 \\
\hline 18 & Pendapatan RT buruh padi & $\operatorname{Rp} 000$ & $6,498.2$ & -2.90 & -1.04 & -1.66 \\
\hline 19 & Pendapatan RT usaha non pertanian & $\operatorname{Rp} 000$ & $7,825.4$ & 25.43 & 10.18 & 16.42 \\
\hline 20 & Total pendapatan RT & $\operatorname{Rp} 000$ & $32,733.8$ & 29.58 & 11.04 & 0.88 \\
\hline 21 & Nilai konsumsi pangan & $\operatorname{Rp} 000$ & 13833 & 21.23 & 7.81 & 5.56 \\
\hline 22 & Nilai konsumsi non pangan & $\operatorname{Rp} 000$ & 8107.2 & 20.13 & 7.51 & 1.05 \\
\hline 23 & Total nilai konsumsi $(21+22)$ & $\operatorname{Rp} 000$ & 21940.2 & 20.82 & 7.70 & 3.90 \\
\hline 24 & Total nilai investasi SDM & $\operatorname{Rp} 000$ & 4652.3 & 40.01 & 14.99 & -0.42 \\
\hline 25 & Total pengeluaran RT $(23+24)$ & $\operatorname{Rp} 000$ & 26592.5 & 24.18 & 8.97 & 3.14 \\
\hline 26 & Pengeluaran perkapita perbulan & $\operatorname{Rp} 000$ & 570.1 & 24.61 & 8.96 & 0.77 \\
\hline 27 & Persentase Penduduk miskin & $\%$ & 30.56 & -6.42 & -2.60 & -15.45 \\
\hline
\end{tabular}

Sumber : Data Primer 2017, diolah

Keterangan $\quad$ Simulasi S2 : Kenaikan HPP Gabah 10 persen

Simulasi S3 : Kenaikan nilai PKH sebesar 100 persen

Simulasi S5 : Kombinasi S2 dan S3

Bertolak-belakang dengan dampak hasil simulasi peningkatan harga pupuk, peningkatan harga GKP berdampak positif terhadap seluruh variabel kinerja ekonomi rumahtangga petani usaha padi. Hal ini sejalan dengan penelitian Kusnadi (2005), bahwa kebijakan memperbaiki harga produk usahatani merupakan kebijakan yang berdampak positif pada kinerja usahatani.

Peningkatan harga GKP pada model secara langsung mempengaruhi luas lahan garapan (LLAHAN). Hal ini menunjukkan bahwa kenaikan harga output memberi insentif bagi rumahtangga petani untuk meningkatkan luas lahan garapan. Peningkatan luas lahan garapan di sini sebenarnya diterjemahkan sebagai peningkatan intensitas tanam selama satu tahun, bukan perluasan penguasaan lahan. Peningkatan luas lahan garapan pada gilirannya berdampak pada peningkatan produksi yang mengakibatkan peningkatan pada penerimaan usahatani padi. Peningkatan harga GKP sebesar 10 persen berdasarkan model menyebabkan peningkatan penerimaan usaha padi rumahtangga penerima $\mathrm{PKH}$. Peningkatan tersebut pada persentase yang relatif sama pada kedua strata lahan. Pada biaya input yang relatif tidak terlalu berubah, peningkatan ini menjadikan pendapatan dari usahatani padi meningkat, sehingga total pendapatan rumahtangga juga meningkat. Pendapatan yang siap dibelanjakan ini akan memengaruhi pengeluaran rumahtangga baik pangan 
maupun non pangan. Demikian pula halnya dengan investasi sumberdaya manusia.

Peningkatan pengeluaran selanjutnya memicu rumahtangga untuk lebih banyak memberikan curahan waktu kerjanya baik pada usahatani padi maupun usaha non padi sehingga total penawaran curahan waktu kerja meningkat. Peningkatan total curahan waktu kerja pada usaha padi akan berdampak pada peningkatan produksi padi. Hal ini menunjukkan bahwa dampak perubahan harga output lebih responsif terhadap kinerja ekonomi rumahtangga dibandingkan dampak perubahan harga input. Disisi lain, kenaikan harga gabah juga berdampak terhadap peningkatan total penawaran curahan waktu kerja. Simulasi kebijakan ini juga berdampak kepada meningkatnya pengeluaran perkapita sebesar 24.61 persen, sehingga jika dibandingkan dengan garis kemiskinan, jumlah penduduk miskin pada kelompok rumahtangga usaha padi penerima $\mathrm{PKH}$ menurun hingga 6,42 persen.

\section{Simulasi 3: Kenaikan Nilai Transfer Tunai PKH Sebesar 100 Persen}

Salah satu tujuan PKH adalah mengurangi beban pengeluaran dan meningkatkan pendapatan rumahtangga miskin dan rentan. Simulasi perubahan kebijakan PKH sebesar 100 persen agar terlihat dampak shock peningkatan PKH. Hal ini mengingat proporsi besaran nilai PKH terhadap pendapatan dinilai masih dianggap sangat kecil jika dibanding dengan rumatangga sasaran di Meksiko sebesar 20 persen dari pendapatan mereka (Todd et al. 2010). Dampak simulasi peningkatan nilai transfer disajikan pada Tabel 4 dan 5 (kolom S3).

Tabel 1 menjelaskan bahwa peningkatan nilai transfer sebesar 100 persen berdampak positif terhadap seluruh variabel kinerja ekonomi rumahtangga usahatani padi di Kabupaten Karawang, meskipun tidak terlalu besar. Peningkatan transfer tunai secara langsung menaikkan pendapatan total rumahtangga. Selain itu, kebijakan ini juga menaikkan tingkat kesempatan kerja, baik penawaran maupun permintaan waktu kerja, baik disektor usahatani padi maupun diluar usaha pertanian. Meningkatnya tingkat curahan waktu kerja rumahtangga pada gilirannya akan meningkatkan pendapatan. Peningkatan transfer tunai secara tidak langsung meningkatkan luas lahan garapan. Peningkatan luas lahan garapan ini akan meningkatkan total produksi dan marketed surplus petani usaha padi. Meskipun peningkatan luas lahan garapan juga akan meningkatkan biaya usahatani karena meningkatnya permintaan pupuk, namun total penerimaan usaha padi lebih besar dari pada biayanya, sehingga pendapatan dari usahatani padi meningkat.

Program perlindungan sosial dapat mengurangi hambatan ekonomi untuk mengakses layanan pendidikan, gizi dan kesehatan, dan berkontribusi pada peningkatan ketahanan pangan dan keanekaragaman makanan. Di daerah pedesaan, perlindungan sosial dapat meningkatkan penggunaan sumber daya yang lebih efisien dan memungkinkan rumah tangga pedesaan miskin untuk berinvestasi dalam kegiatan mata pencaharian yang lebih berisiko tetapi lebih besar menghasilkan, terutama dengan mengurangi kendala likuiditas dan mendukung mobilitas tenaga kerja (Slater dan McCord, 2009).

Pada simulasi ini pengeluaran perkapita meningkat sebesar 8.96 persen, sehingga jika dibandingkan dengan garis kemiskinan, jumlah penduduk miskin pada kelompok rumahtangga usahatani padi penerima PKH turun sebesar 2.60 persen yang semula sebesar 30.56 persen menjadi 27.95 persen.

\section{Simulasi 4: Kombinasi Simulasi 1 dan 3}

Simulasi ini bertujuan untuk mengetahui apakah peningkatan PKH pada besaran tertentu dapat memberikan kompensasi peningkatan biaya produksi yang ditanggung petani karena meningkatnya harga pupuk. Melalui simulasi kebijakan ini, diharapkan sistem distribusi pupuk bersubsidi dan tingkat kesejahteraan petani tidak berubah. Kombinasi simulasi dapat dilihat pada Tabel 4 (kolom S4). Pada tabel tersebut terlihat bahwa kombinasi kebijakan dapat mengembalikan kesejahteraan yang hilang sebagai akibat akibat peningkatan harga pupuk. Hal ini menjelaskan bahwa peningkatan cash 
program berupa tambahan $\mathrm{PKH}$ sebesar 100 persen dapat dijadikan kompensasi kebijakan yang dapat menurunkan kesejahteraan petani. Pada simulasi ini pengeluaran perkapita menurun sebesar 3,82 persen, sehingga jumlah penduduk miskin pada kelompok rumahtangga usahatani padi penerima PKH meningkat 3,99 persen yang semula sebesar 26,56 persen menjadi 30,55 persen.

Penelitian ini tidak berbeda jauh dengan penelitian Pace et al. (2017), bahwa ada sinergi antara kebijakan subsidi pupuk dan kebijakan cash transfer kepada petani miskin. Selain itu menurut Perera et al. (2016), cash program lebih disukai daripada subsidi dalam bentuk natura karena produksi keseluruhan diperkirakan akan meningkat jika pemerintah memberikan transfer uang tunai yang setara dengan nilai subsidi pupuk. Sejalan dengan itu, menurut Susilowati (2016) dengan melaksankan opsi kebijakan kenaikan HET secara bertahap, maka selama lima tahun (2016 - 2020), jumlah penghematan APBN yang berasal dari subsidi pupuk ini akan mencapai antara 85 hingga 99 triliun rupiah. Sementara jika asumsi jumlah penerima $\mathrm{PKH}$ adalah tetap, maka penambahan nilai PKH selama lima tahun tersebut hanya sebesar 12 triliun rupiah. Dengan demikian, penghematan APBN secara netto untuk sinergi kedua kebijakan ini selama lima tahun berkisar antara 73 hingga 87 triliun rupiah.

\section{Simulasi 5: Kombinasi Simulasi 2 dan 3}

Tabel 5 (kolom S5) merupakan hasil kombinasi simulasi kebijakan peningkatan harga GKP sebesar 10 persen dengan simulasi peningkatan nilai transfer tunai sebesar 100 persen. Kombinasi simulasi ini dimaksudkan untuk menjelaskan adanya sinergitas antar kebijakan. Hal ini dapat diketahui dari hasil kombinasi kebijakan yang berdampak lebih baik bagi kinerja ekonomi dan kesejahteraan rumahtangga petani dibanding masing-masing simulasi kebijakan tunggal.

Terlihat dari tabel tersebut bahwa kombinasi kebijakan ini berdampak positif pada seluruh kinerja ekonomi dan kesejahteraan rumahtangga. Hal ini ditandai dengan peningkatan yang terjadi pada produksi gabah, total penerimaan dan pendapatan usaha padi, total curahan waktu kerja pada usaha padi, total penawaran curahan waktu kerja rumahtangga, total pendapatan dan total pengeluaran rumahtanga. Peningkatan pada produksi gabah, total penerimaan, dan pendapatan usaha padi. Hal ini disebabkan karena pada adanya peningkatan dari pendapatan non pertanian yang lebih besar. Peningkatan ini sebagai konsekuensi dari peningkatan total curahan waku kerja non pertanian rumahtangga yang lebih besar pada strata ini.

Peningkatan pendapatan baik secara total maupun pada usaha padi dan non pertanian juga sebagai akibat adanya sinergi pada kedua kebijakan. Hal ini terlihat dari tiap-tiap variabel endogen yang persentase peningkatannya lebih besar dibandingkan dengan penjumlahan satu-satu masingmasing simulasi tunggal kebijakannya pada variabel endogen yang terpilih. Kombinasi kebijakan ini juga bersinergi dalam rangka meningkatkan kesejahteraan dan menurunkan kemiskinan.

Namun demikian, menurut Doward et al. (2006) kombinasi kebijakan pertanian yang bersifat subsidi dan program perlindungan sosial menjadi suatu hal yang tumpang tindih. Sesunggunya agenda kebijakan perlindungan sosial dimunculkan sebagai kompensasi dari kebijakan liberalisasi pasar yang membatasi ruang lingkup intervensi negara dalam ekonomi.

Kebijakan liberasi pasar yang dimaksud antara lain adalah harga pembelian pemerintah atau harga subsidi input. Dengan kata lain, kebijakan perlindungan sosial baru diperlukan karena aspek perlindungan sosial yang disediakan oleh kebijakan intervensi negara berupa intervensi harga telah dihilangkan. Lebih lanjut, Doward et al. (2006) menyarankan bahwa selama transisi menuju liberalisasi pasar beberapa aspek kebijakan perlindungan sosial dapat diintegrasikan ke dalam kebijakan pembangunan pertanian tetapi secara kelembagaan berada di bawah bendera kebijakan perlindungan sosial.

Pada kombinasi simulasi ini pengeluaran perkapita naik sedikit sebesar 
11,03 persen, sehingga jumlah penduduk miskin pada kelompok rumahtangga usahatani padi penerima PKH menurun sebesar 13,37 persen yang semula sebesar 26,56 persen menjadi 13,09 persen.

\section{SIMPULAN DAN IMPLIKASI KEBIJAKAN}

\section{Simpulan}

Berdasarkan hasil dan pembahasan, dapat disimpulkan beberapa hal sebagai berikut:

1. Model ekonomi rumahtangga petani usaha padi penerima PKH yang dibangun dapat diaplikasikan kemampuannya untuk melakukan simulasi kebijakan, baik kebijakan pertanian, kebijakan program perlindungan sosial, maupun kombinasi kedua kebijakan. Model dapat digunakan untuk mengevaluasi alternatif dampak kebijakan yang relevan terhadap kesejahteraan rumahtangga petani usaha padi dan perubahan persentase penduduk miskin.

2. Perubahan kebijakan pertanian berupa pengurangan subsidi pupuk dan peningkatan HPP gabah berdampak pada perubahan perilaku rumahtangga petani berupa keputusan produksi, konsumsi, dan alokasi waktu kerja rumahtangga. Khusus perubahan HPP gabah dan $\mathrm{PKH}$, kedua kebijakan ini berdampak pada peningkatan kesejahteraan rumahtangga. Selain itu juga berguna mengembalikan kesejahteraan yang hilang sebagai akibat pengurangan subsidi pupuk dalam rangka penghematan anggaran. Selain itu, instrumen PKH secara khusus juga mampu meredistribusi pendapatan sehingga memiliki daya dorong yang lebih kuat dalam mengurangi jumlah penduduk miskin di pedesaan. Kebijakan HPP gabah dan $\mathrm{PKH}$ juga dapat bersinergi dan memungkinkan sebagai suatu alternatif pilihan dalam meningkatkan kesejahteraan petani usaha padi dan menurunkan jumlah penduduk miskin di pedesaan.

\section{Implikasi Kebijakan}

Beberapa implikasi kebijakan yang dapat disarankan dari penelitian ini sebagai berikut:

1. Model ekonomi rumahtangga petani usaha padi penerima PKH dapat dikembangkan dan digunakan pada daerah lain dan skala yang lebih luas untuk menganalisis integrasi kebijakan pertanian dan program perlindungan sosial serta program subsidi pangan lainnya. Pengembangan model sebagai bahan untuk program peningkatan kesejahteraan dan pengentasan kemiskinan.

2. Dalam rangka penghematan anggaran, pemerintah dapat menempuh kebijakan pengurangan subsidi pupuk secara bertahap. Namun kebijakan ini hendaknya dibarengi dengan peningkatan besaran nilai program perlindungan sosial bagi rumahtangga sasaran. Selain itu, mengingat besaran nilai PKH sebagai bentuk program perlindungan sosial yang diterima petani saat ini relatif masih kecil. Perubahan yang tidak terlalu besar tidak akan berdampak terhadap upaya peningkatan usaha pertanian, peningkatan kesejahteraan petani, dan penurunan jumlah penduduk miskin di pedesaan.

\section{DAFTAR PUSTAKA}

Becker GS. 1965. A Theory of the Allocation of Time. The economic journal 75 (299):493-517.

Boone R, Covarrubias K, Davis B, Winters P. 2013. Cash transfer programs and agricultural production: the case of Malawi. Agricultural Economics 44(3):365-378.

[BPS] Badan Pusat Statistik. 2017. Kabupaten Karawang Dalam Angka 2017. Publikasi BPS Kabupaten Karawang 2017

Dorward A, Sabates-Wheeler R, MacAuslan I, Buckley CP, Kydd J, Chirwa E. 2006. Promoting agriculture for social protection or social protection for agriculture: Strategic policy and 
research issues. Growth and Social Protection Discussion Paper 4.

Komarek AM, Drogue S, Chenoune R, Hawkins J, Msangi S, Belhouchette H, Flichman G. 2017. Agricultural household effects of fertilizer price changes for smallholder farmers in central Malawi. Agricultural Systems 154:168-178. doi:10.1016/j.agsy.2017.03.016)

Kuotsoyiannis, A. 1977. Theory of Econometrics: An Introductory Exposition of Econometric Methods. Second Edition. The Macmillan Press Ltd, London.

Pace N, Daidone S, Davis B, Handa S, Knowles M, Pickmans R. 2017. One Plus One can be Greater than Two: Evaluating Synergies of Development Programmes in Malawi. The Journal of Development Studies:1-38.

Perera M, Rathnayake R, Fernando P. 2016. An Economic Analysis based on Equivalent Variance of the Fertilizer Subsidy: A Case of Mahaweli System H in Sri Lanka. 13th International Conference on Business Management, Colombo.

Pyndick, R.S. and D.L. Rubenfield. 1998. Econometric Model and Economic Forecast. Sixth Edition. Irwin $\mathrm{Mc}$ Graw-Hill, Boston.

Putri EIK, Novindra N, Nuva N. 2013. Dampak Kebijakan Harga Pembelian Petani Gabah terhadap Kesejahteraan Petani: Suatu Simulasi. Jurnal Ekonomi dan Pembangunan Indonesia 13(2):125-142.
Rusastra IW, Kustiari R, Pasandaran E. 2016. Dampak penghapusan subsidi pupuk terhadap penggunaan pupuk dan produksi padi nasional. Jurnal Agro Ekonomi 16(1-2):31-41.

Singh, I., L. Squire, and J. Strauss. 1986. Agricultural Household Models: Extention, Applications, and Policy. The Johns Hopkins University Press, Baltimore.

Slater R, McCord A. 2009. Social Protection, Rural Development and Food Security: Issues paper on the role of social protection in rural development. London, UK: Overseas Development Institute.

Susilowati SH. 2016. Urgensi dan Opsi Perubahan Kebijakan Subsidi Pupuk. Analisis Kebijakan Pertanian 14(2):163-185.

Taylor JE, Adelman I. 2003. Agricultural household models: genesis, evolution, and extensions. Review of Economics of the Household 1(1):33-58.

Tirivayi N, Knowles M, Davis B. 2016. The interaction between social protection and agriculture: A review of evidence. Global Food Security 10:52-62. doi:10.1016/j.gfs.2016.08.004

Todd JE, Winters PC, Hertz T. 2010. Conditional Cash Transfers and Agricultural Production: Lessons from theOportunidadesExperience in Mexico. Journal of Development Studies 46(1):39-67. doi:10.1080/00220380903197945 
